脺・胆管合流異常に膵頭部癌をともなった 1 例

\begin{tabular}{lrrrrr}
\multicolumn{8}{c}{ 机愰医科大学第 1 外科 } & \\
吉武 & 英子 & 平田 & 公一 & 吉田 & 和義 \\
向谷 & 充宏 & 白川 & 拓 & 高室 & 雅 \\
小林 & 謙二 & 白松 & 幸爾 & 早坂 & 滉
\end{tabular}

\title{
A CASE OF AN ANOMALOUS JUNCTION OF THE PANCREATICO-BILIARY DUCTAL SYSTEM WITH CARCINOMA OF PANCREATIC HEAD
}

\author{
Eiko YOSHITAKE, Koichi HIRATA, Kazuyoshi YOSHIDA, \\ Mitsuhiro MUKAIYA, Taku SHIRAKAWA, Tadashi TAKAMURO, \\ Kenji KOBAYASHI, Koji SHIRAMATSU and Hiroshi HAYASAKA
}

1st Department of Surgery, Sapporo Medical College

索引用語：腪・胆管合流異常，膵頭部癌

はじめに

最近, 腪・胆管合流異常 ${ }^{11}$ と胆道癌2) 4) 扎よび䐙癌発 生 ${ }^{5)}$, あるいは慢性荤炎6) との関連性について注目され てきた. とくに胆道癌との関連では数多くの検討が成 されてきたが䐙疾患とのそれは少ない。

今回われわれは, 腪・胆管合流異常之荤頭部癌を合 併した 1 症例を経験したので, 若干の文献的考察を加 孚報告する。

患者：63歳。男性

主訴：全身倦总感。食思不振, 黄疸

家族歴：昭和 53 年に糖尿病を指摘されるも放置して いた.

現病歴: 昭和 59 年 7 月下旬ころより, 易疲労感, 食 思不振, 体重減少が出現し, 8 月初旬より全身瘦㾕感 む加わる．家族に黄疸を指摘され，8 月24日某病院を 受診. 閉塞性黄疸および糖尿病之診断され, 精査, 治 療を目的として当科を紹介され，8月29日入院となる.

現症：瘵瘦を呈し，栄養不良で，貧血。黄疸を認め た. 胸部に異常所見なく, 腹部は平坦で軟, 圧痛およ び腫瘤を認めず，肝・脾・腎は触知しなかった。

入院時一般検查所見: 赤血球 303 万 $/ \mathrm{mm}^{3}$, へモグロ ビン $10.0 \mathrm{~g} / \mathrm{dl}$, ヘマトクリット $30.0 \%$ と貧血を呈し, ま た総ビリルビン $19.8 \mathrm{mg} / \mathrm{dl}$, 直接ビリルビン $19.5 \mathrm{mg} /$

$<1985$ 年 9 月11日受理 $>$ 別刷請求先：平田 公一

厂060 札幌市中央区南 1 条西16丁目 札幌医科大学 第 1 外科 dl と閉塞性黄疸を示した（表 1 ）。また GOT 47KU な ど軽度の肝細胞性障害もともなった。辇内分泌機能検 查として $50 \mathrm{~g}$ 経口糖負荷試験を行ったところ，空腹時 血糖 $327 \mathrm{mg} / \mathrm{dl}$ と明らかに高値を呈し，負荷後経時的 に血糖が上昇する，いわゆるリニアパターンを示し， また内因性インスリン定量においてもはとんど反応の ない，耐桾能低下状態を認めた。嵫外分泌機能検査と しては Pancreatic Function Diagnostant (PFD)を 施行し, 正常值を得ている。なお，血清特よび尿了ミ ラーゼ值はいずれも正常であった，胸・腹部 X 線所見 に異常はない。

腹部超音波所見：膵頭部莘内に局在する直径約 1.5 $\mathrm{cm}$ の円形の低ェコーレベル領域を認める。腪体・尾部 の䐉管は抬張しているが，実質部位はほぼ均一のエ コーレベルを示した。肝・脾・腎および大動脈周囲リ

表 1 入院時検査所見

\begin{tabular}{|c|c|c|c|c|c|c|}
\hline $\begin{array}{l}\text { RBC } \\
\text { W } \\
\text { WBC } \\
\text { T.P } \\
\text { AIb } \\
\text { BII } \\
\text { Q-BiI } \\
\text { GOT } \\
\text { GPT } \\
\text { LDP } \\
\text { TTT } \\
\text { ZTT } \\
\end{array}$ & \multicolumn{2}{|c|}{$\begin{array}{l}4.8 \mathrm{~g} / \mathrm{dl} \\
2.4 \mathrm{~g} / \mathrm{dl} \\
19.8 \mathrm{mg} / \mathrm{dl} \\
19.5 \mathrm{mg} / \mathrm{dl} \\
47 \mathrm{kU} / \mathrm{kJ} \\
29 \mathrm{KU} \\
454 \mathrm{IU} / \ell \\
0.5 \mathrm{KU} \\
2.3 \mathrm{KU} \\
\end{array}$} & \multicolumn{3}{|c|}{$\begin{array}{ll}\text { ALP } & 519 \mathrm{IU} / \mathrm{l} \\
\text { rGTP } & 179 \mathrm{mU} / \mathrm{ml} \\
\text { Amyl } & 112 \mathrm{IU} / \mathrm{l} \\
\mathrm{chE} & 0.39 \Delta \mathrm{PH} \\
\text { Chol } & 210 \mathrm{mg} / \mathrm{d} \\
\text { PED } & 58.4 \%\end{array}$} & \\
\hline \multicolumn{7}{|c|}{$50 \mathrm{~B} \mathrm{GTT}$} \\
\hline & & 新 & 30 分 & 60 A & 120 分 & 180 分 \\
\hline \multirow{2}{*}{\multicolumn{2}{|c|}{ 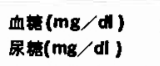 }} & 327 & 420 & 384 & 372 & 499 \\
\hline & & 24 & & 3.6 & 6.5 & 6.9 \\
\hline \multicolumn{2}{|c|}{ インスリン $(\mu \mathrm{dU} / \mathrm{ml})$} & 3 & 4 & 3 & 4 & 4 \\
\hline
\end{tabular}


ンパ節に異常所見はない（図 1).穿刺吸引細胞診で class Vであった。

腹部 Computed axial tomography (CT) 所見：膵 頭部はやや腫大し, 周辺部は Contrast study で不均一 に増強されるが，その中央部に比較的境界鮮明な低濃 度領域が確認された。体・尾側荤管は拡張していた(図 2 ).

胆道造影所見：経皮経肝的胆管ドレナージ (PTCD) チューブからの胆管造影では下部胆管の完全閉塞を認 めた。な和結石の合併はなく, 肝外胆管の鸾腫状执張

\section{図 1 超音波検査}

膵頭部に円型の低エコーレベル領域を認める

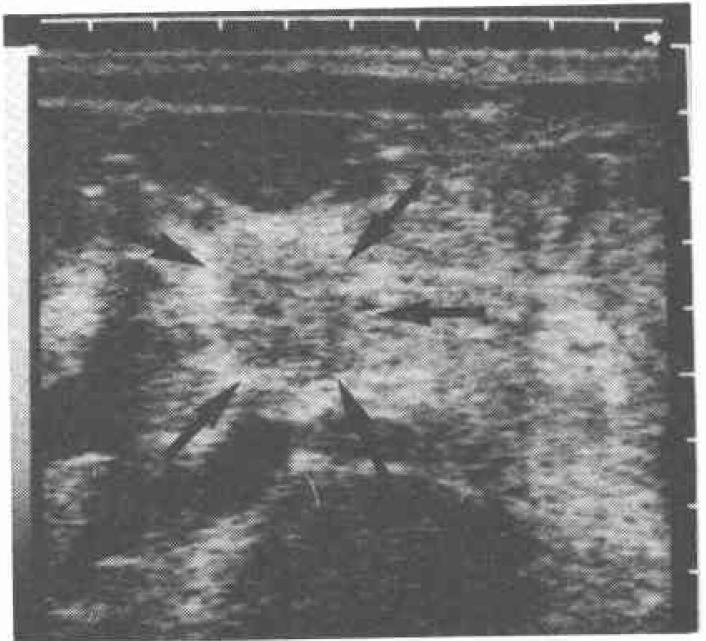

矢印：腫場部分

図 2 CT

脺頭部に周辺部は不均一にエンハンスされるが，中 央部は境界鮮明な低濃度領域が認められる

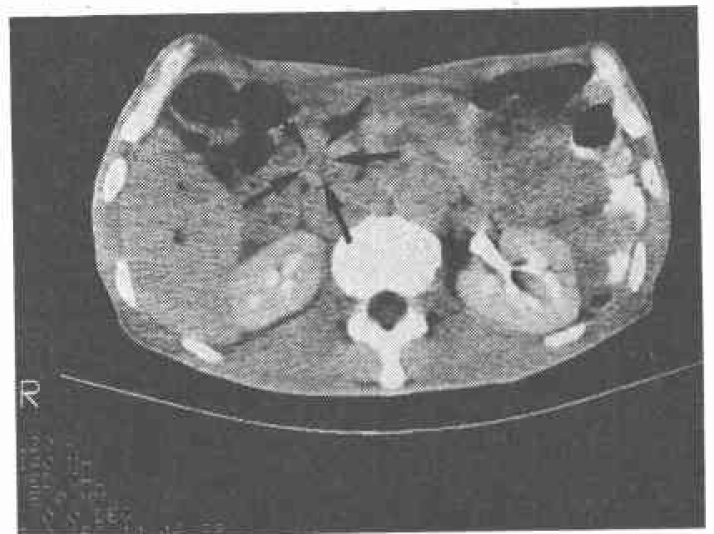

矢印：腫湯部分
はなかった（図３）。

血管造影所見：膵頭部アーケードがやや開大してい る以外に異常所見はなかった。

入院後臨床経過：减黄を目的として 9 月 3 日 PTCD 施行. 17 日後, 総ビリルビン値は, $5.1 \mathrm{mg} / \mathrm{dl}$ に 減少した。

上述の検査所見から腪頭部癌の診断で 9 月 18 日手術

図 3 PTCD

下部胆管の閉塞之胆管の拡張が認められる

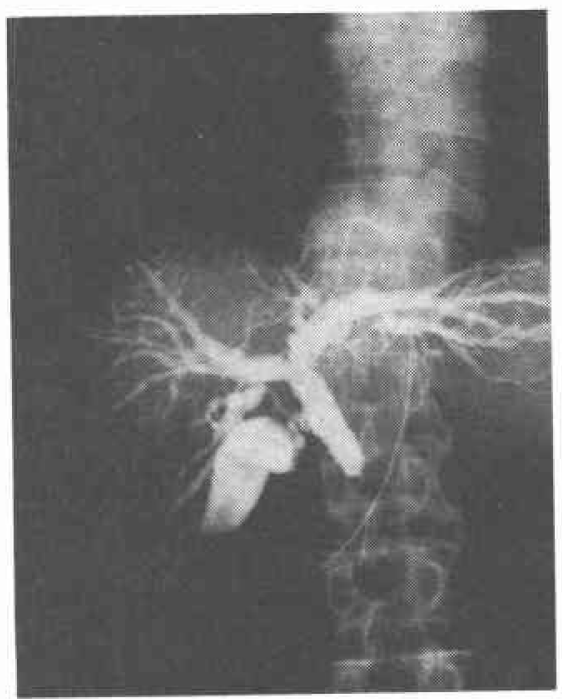

因 4 摘出標本䐙頭部所見

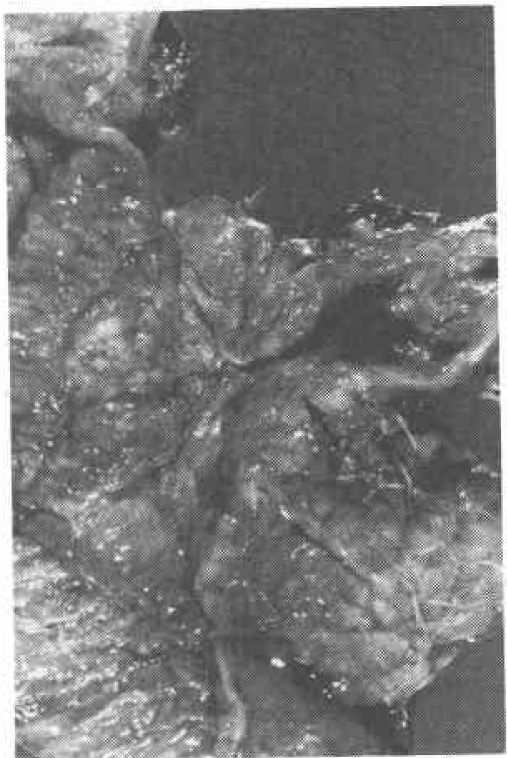

矢印：腫痬部 
施行.

手術所見：膵は全体に硬化を示したが，所属りンパ 節の腫大は著しくなく, 周辺他藏器にも異常はなかっ た. 膵頭十二指腸切除術, 再建は P-D-IIIBを行った。

摘出標本肉眼所見：摘出材料（図 4) 拉よびその シューマ（図 5) を示した，その所見を要約すると，

(1) 膵頭部に $1.8 \times 1.7 \times 1.2 \mathrm{~cm}$ 大の腫瘤型小膵癌を認 める.（2）腪全体で，いわゆる実質が減少し結合織に 置換し一様に硬化を示し, 慢性独炎合併を疑わせた。

（3）拡張した胆管が十二指腸筋層外の膵頭腫瘤発生部 に一致する脇管に合流している，その後十二指腸乳頭 部まで約 $4 \mathrm{~cm}$ の共通管を形成するいわゆる腪胆管合 流異常を認めた。（4）胆衰と腪頭部領域に浮腫性変化

図 5 摘出標本模式図

膵頭部の胆管之膵管の合流部に腫場を認め，合流部 は明らかに十二指腸筋層外に存在する

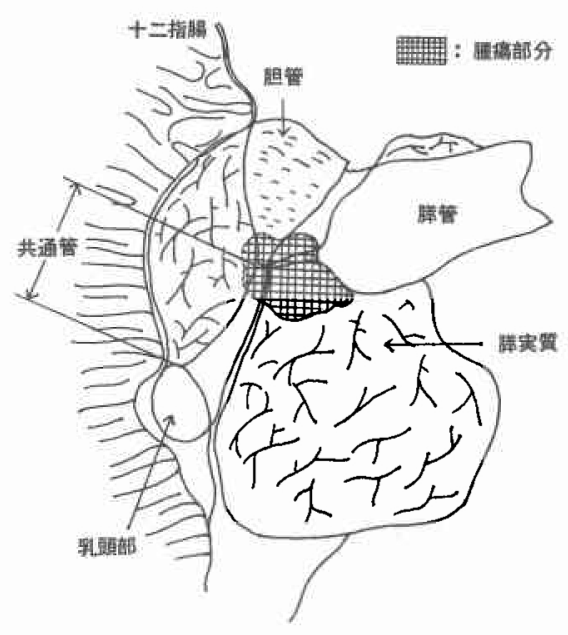

図 6 病理組織所見

腺上皮は, grade Iから V までの異型があり炎症細 胞の浸潤と線維化が目立った

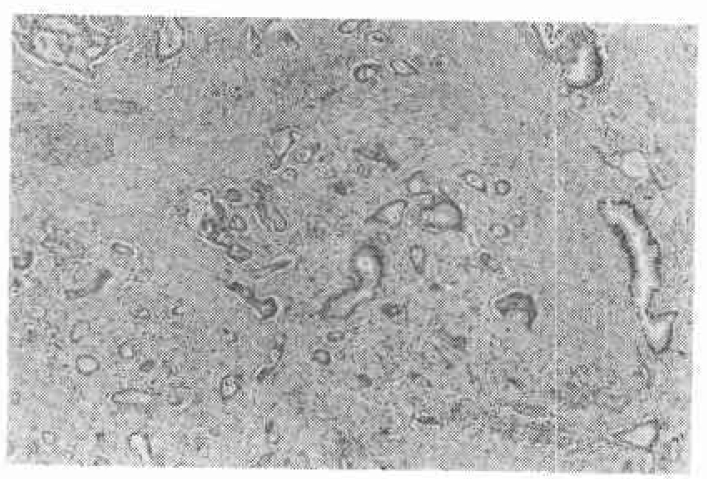

を認めた，以上，手術所見および摘出標本肉眼所見か ら, 膵癌取り扱い規約に従って要約すると, $\mathrm{ph}, \mathrm{T}_{1}$, 腫瘤型, $\mathrm{S}_{0}, \mathrm{Rp}_{1}, \mathrm{Ch}_{3}, \mathrm{DU}_{0}, \mathrm{~V}_{1}, \mathrm{~A}_{0}, \mathrm{H}_{0}, \mathrm{~N}(-)$, $\mathrm{M}($ ( ) で Stage II と考学られた.

病理組織学的所見：高分化型管状腺癌で大小不同の 不整形の核をもつ細胞が周囲に結合織の誘導を伴いな がら浸潤增殖していた，非癌部では，膵全体に资症の 持続または反復によると思われる不規則な実質の脱落 と線維化，好中球とリンパ球の漫潤を認めた。また苹 管上皮は, 反応性の増生と思われる Grade I から明ら かに癌化した Grade V までの,さまざまな異型を示し た（図6).

以上, 病理組織学的診断を要約すると, tubular adenocarcinoma, well differentiated type, INF $\gamma, \mathrm{ly}_{2}$, $\mathrm{v}_{1}, \mathrm{~d}(+), \mathrm{pw}(-), \mathrm{ch}_{1}, \mathrm{du}_{0}, \mathrm{~s}_{0}$, ew $(-) \mathrm{n}_{16}(-)$ $\mathrm{n}_{17 a}(+)$.

\section{考 案}

脞・胆管合流異常1) と胆道・胆囊癌との関係について は多くの研究・報告がみられる21 4). 今回報告した症例 の特徵は，(1)合流部に苹癌の発生を認めたこと，(2) 荤体・尾部はもちろん腫場による憎管閉塞部の膵実質 すなわち膵頭・鈎部にも好中球・リンパ球の浸潤をと もなら炎症と結合識の増生を認めたことである。すな わち, 荤・胆管合流異常之膵癌に, 二次性膵炎を合併 していると考兄られた。

先ず発癌との関連について検討したい，本症例の場 合はまず第 1 に合流異常による逆流胆汁の発癌過程へ の関与も考兄られる。それは逆流した胆汁のプロモー ターとしての可能性である。たとえばデオキシュール 酸は肝癌7や大腸癌8のプロモーターであることが知 られている。現在, 满癌発生のそれについては明らか にはされていないが，もしデオキシコール酸をはじめ とする変性胆汁が, 膵管へ逆流・らっ滞しやすい病態 下では，腪管上皮はより長時間にわたり，かつより高 濃度の接触をうけ癌化する可能性がある.

第 2 には, 既存の慢性腪炎の腪管上皮再生過程が膵 癌発生の high-risk-state であるとする考兄である。荤 管上皮の増生あるいは化生变化の原因には, 慢性资症, 化学的, 物理的刺激あるいは苹管閉塞などがあげられ

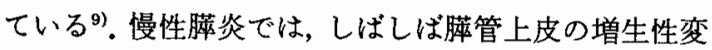
化をともなうことが知られており ${ }^{10)}$ ，臨床例の検討か らも苹管上皮増生が前癌病変として重要視されてい る.すなわち(1)脺管上皮増生は, 他の膵疾患に比へ荤 癌例では著しく高率に認められている。(2)荤管上皮増 
生が加齢とともに増加するが，膵癌例では非癌部に， 同年齢層の非荤疾患症例の々九と比べると約10倍の高 頻度で存在する。(3)脞管上皮増生は, 苹癌病変周辺に 多く，しかもそこでは異型度の高い細胞が多くみられ る. (4) Carcinoma in situは異型の少ない病巣中にも しばしば認められ，相互の移行像も認められる。(5)脞 管上皮増生細胞において粘液組織化学的に荤癌組織と 同質の粘液組成が証明されている の荤管過形成を非乳頭状，乳頭状，異型性の三段階に 分けている。炎症後の再生過程の段階で非乳頭状過形 成が生ずる時点に括ける発癌の関与を示唆している。

合流異常の病態は, 胆汁と腪液の相互の逆流を制御 する括約筋の正常な作用の脱落によるもので, 莝液と 胆汁とが王勾配徒いお互いに逆流しうることに根ざ している.すなるち通常では荤液が圧勾配により胆道 系に逆流するが，食後胆儴が収縮すると総胆管内圧が 高まり括約䈘作用が不十分なため，胆汁が萍管内に流 入する可能性がある.今回の症例のような Ib 型合流異 常は，両管合流部の相対的狭害により，胆汁あるいは 羘液のうっ滞により合流部の紡錘状扗張が生じるとさ $れ^{13)}$,このため炎症をくり返し, 慢性荤炎に至る可能性 がある。しかし合流異常にみられる慢性䐽炎の諸家の 報告は $24 \%{ }^{14)}, 33 \%{ }^{15)}$ と頻度の高いものもあるが, 合流 異常の存在がただちに膵炎発生には結びつかないとす る意見る多いようである ${ }^{16)}$.

\section{結語}

膵・胆管合流異常に腪頭部癌, 二次性慢性莝炎を合 併した症例を報告するとともに，随伴病変の成因ある いは相互関連性について考察を加えた。膵頭部癌につ いては，まさに合流部に存在していた，この発癌過程 に, 合流異常という病態が関与しうるか否かについて 考察を加えた.

\section{文献}

1）古味信彦：膵胆管合流異常症。外科治療 42 ： $585-594,1980$

2）杉原順一, 関田幹雄, 斉藤洋一：荤胆管合流異常と 癌。胆と䑏 $3: 487-495,1982$
3）黑田 慧, 小西陽一，小塚貞雄：膵·胆道の前癌病 変をめぐって。胆と荤 $2: 1618-1700,1981$

4) 木下博明, 長田策一, 街 保敢汪か：茦・胆管合流 異常を合併した胆囊癌一自験例 7 例と本邦報告例 の検討一。胆と腪 $2: 1701-1709,1981$

5) Eugene PD, Roy GS, Williams FT: Relationship between pancreaticobiliary ductal anatomy and pancreatic ductal and paren. chymal histology. Cancer $49: 361-368,1982$

6）宮野武,下村 洋, 出口英一注か：胆捇管合流異 常実験モデルにみられた慢性膵炎。医のあゆみ $126: 671-672,1983$

7) Tsuda $H$, Masui $T$, Imida $K$ et al: Proctive effect of primary and secondary bile acids on th induction of r-glutamyl transpeptidase-positive liver cell focias a possible endogenous factor for hepatocarcinogenesis in rats. GANN 75 : $871-875,1984$

8) Raddy BS, Weisburger JH, Wynder EL: Bile salts as tumor promotors. In: Carcinogenesis. vol 2. Edited by TJ Slaga, A Sivak and RK Boutwell, New York, Rauen Press, 453-464, 1978

9) 松本道男, 乾 道夫, 橋本敬祐注か：脞炎. 橋本敬 祐編, 羘の形態と機能, 東京, 宇宙堂八十書店, 1981, p171-194

10）須田耕一, 小松勝彦: 朠の老化. 橋本敬祐編, 膵の 形態子機能, 東京, 宇宙堂八十書店, 1981, p92-102

11）和田祥元, 黒田 慧：腪癌の前癌病変とその臨床 的意義. 外科治療 $45 ： 63-68,1981$

12）小塚貞雄：䐙癌の発生母地. 胆も橧 $2: 1657$ (代 1663,1981

13）宮野 武, 駿河敬次郎, 松本道男法か：荤・胆管合 流異常症一脞病変を中心に一. 肝・胆 - 㖴 8 ： $533-540,1984$

14）水元龍二, 日高直昭, 佐々木英人：実験的急性橧 炎, 最新医 $34: 1636,1979$

15）宮田 晋, 涉江 正, 山口淳江ほか：腪疾患から及 た获・胆管合流異常. 日本臟病研究会プロシーディ ングス 11: 164, 1981

16）土岐文武, 大井 至, 竹内 正活か：苹・胆管合流 異常と苹炎一主として满管像から一. 胆と滕 3 ： $505-513,1982$ 